\title{
DOSE RESPONSE EFFECT OF Paracoccidioides brasiliensis IN AN EXPERIMENTAL MODEL OF ARTHRITIS
}

Eduardo Alexandre LOTH(1), Samia Khalil BIAZIM(1), José Henrique Fermino Ferreira dos SANTOS(1), Rosana PUCCIA(2), Rosimeire Costa BRANCALHÃO(1), Lucinéia de Fátima CHASCO(1), Rinaldo Ferreira GANDRA(3), Rita de Cássia Garcia SIMÃO(3) \& Marcello Fabiano de FRANCO(4)

\begin{abstract}
SUMMARY
Paracoccidioidomycosis (PCM) is caused by the dimorphic fungus Paracoccidioides brasiliensis $(\mathrm{Pb})$ and corresponds to prevalent systemic mycosis in Latin America. The aim of the present work was to evaluate the dose response effect of the fungal yeast phase for the standardization of an experimental model of septic arthritis. The experiments were performed with groups of 14 rats that received doses of $10^{3}, 10^{4}$ or $10^{5} \mathrm{P}$. brasiliensis ( $\left.\mathrm{Pb} 18\right)$ cells. The fungi were injected in $50 \mu \mathrm{L}$ of phosphate-buffered saline (PBS) directly into the knee joints of the animals. The following parameters were analyzed in this work: the formation of swelling in knees infused with yeast cells and the radiological and anatomopathological alterations, besides antibody titer by ELISA. After 15 days of infection, signs of inflammation were evident. At 45 days, some features of damage and necrosis were observed in the articular cartilage. The systemic dissemination of the fungus was observed in $11 \%$ of the inoculated animals, and it was concluded that the experimental model is able to mimic articular PCM in humans and that the dose of $10^{5}$ yeast cells can be used as standard in this model.
\end{abstract}

KEYWORDS: Paracoccidioidomycosis; Paracoccidioides brasiliensis; Arthritis; Inflammation.

\section{INTRODUCTION}

Paracoccidioidomycosis (PCM) is caused by the dimorphic fungus Paracoccidioides brasiliensis $(\mathrm{Pb})$ and corresponds to a prevalent systemic mycosis in Latin America. Fungal conidia are inhaled from the environment and can spread from the lungs to internal organs and mucocutaneous osteoarticular areas, causing severe granulomatous lesions. PCM affects more than 10 million people and has the highest mortality rates in Southern and Southeastern Brazil. The largest recorded cases of the disease are found in Brazil, with over $80 \%$ of all cases ${ }^{22}$.

The inclusion of PCM as a serious public health problem is due to the fact that it predominantly affects males in their most productive years: approximately $85 \%$ of cases occur between 30 to 59 years of age ${ }^{28,36}$. The high social and economic costs are due not only to the treatment of the disease, but also the sequelae secondary infection, which incapacitates the individual from working ${ }^{26}$.

The accidentally inhaled fungal particles can remain latent in the lungs and later develop into the chronic form of the disease $\mathrm{e}^{4,24}$ or evolve more rapidly into the acute form ${ }^{4,15,34}$. In both forms, the tissues affected develop noticeable compact epithelioid granulomas containing a few viable fungi in their interior and may involve joints ${ }^{4,24,29}$.
The osteoarticular problems caused by $P$. brasiliensis were first reported in $1911^{33}$. Oesteoarticular involvement was observed in up to $20 \%$ of cases in the acute ${ }^{29}$ form and in up to $60 \%$ of chronic cases secondary to systemic involvement, especially in the lungs and $\operatorname{skin}^{8,12}$.

The articular manifestation of PCM is accompanied by signs of intense inflammation and loss of joint function. In these cases, X-ray examinations reveal the destruction of articular cartilage, stroke and joint space narrowing ${ }^{3}$.

Note that scientific knowledge about arthritis has been almost entirely acquired through studies with Staphylococcus aureus ${ }^{20}$. Therefore, PCM joint manifestations have not yet been addressed using experimental models. In this context, the present study aimed to standardize an experimental model of septic arthritis with $P$. brasiliensis in the knees of Wistar rats.

\section{MATERIALS AND METHODS}

The present study was jointly developed at the Laboratory of Clinical Analysis, Education and Research at the State University of West Paraná, Cascavel/PR (UNIOESTE) and Laboratory of Pathology, Federal University of São Paulo (UNIFESP) from January 2011 to July 2012. 
LOTH, E.A.; BIAZIM, S.K.; SANTOS, J.H.F.F.; PUCCIA, R.; BRANCALHÃO, R.C.; CHASCO, L.F.; GANDRA, R.F.; SIMÃO, R.C.G. \& FRANCO, M.F. - Dose response effect of Paracoccidioides brasiliensis in an experimental model of arthritis. Rev. Inst. Med. Trop. Sao Paulo, 56(3): 259-64, 2014.

The experiments were approved by the Research Ethics Committee from UNIFESP-Hospital, São Paulo (Process: CEP No. 1023/10) and from UNIOESTE, Cascavel (Process: CEP No. 67/09).

The experiments were conducted with 84 male Wistar rats (45- to 60-day-old) divided into 14 groups of six animals. The experimental groups (EG) received intravenous articulate viable $P$. brasiliensis yeasts in the right knee joint at different doses. The negative control groups (GCN) received different doses of intra-articular heat-killed yeasts in the knee joint. The second absolute control groups (GCA) received intra-articular doses of $50 \mu \mathrm{L}$ of sterile PBS in the joint.

The yeast suspensions used in EG were obtained from cell masses of strain $\mathrm{Pb} 18$, which were homogenized in sterile PBS. The cellular concentrations of yeast cells $\left(10^{3}, 10^{4}\right.$ and $\left.10^{5}\right)$ were adjusted using a Neubauer chamber. The GCN inoculum was prepared from heat-killed yeast cells $\left(56{ }^{\circ} \mathrm{C}\right.$ for two hours). The inocula were homogenized, and the yeast cells were counted.

Yeast viability was determined using the Trypan blue exclusion method and cells suspensions were used with viability higher than $90 \%$ for GE and non-viable for GCN.

The rats were anesthetized (ketamine and xylazine, $20: 5 \mathrm{mg} \mathrm{kg}^{-1}$, respectively), and, a $50 \mu \mathrm{L}$ cell suspension (concentrations of $10^{3}, 10^{4}$ or $10^{5}$ ) of yeast cells was injected (27-gauge needle) directly into the knee joint of the right hind limb of each animal in the EG. The CGN received the same doses of yeast cells inactivated by heat. The CGA received only sterile PBS in the joint. The animals were sacrificed at two timepoints, 15 and 45 days after the infection date.

During the experiment, daily evaluations of the formation of swelling at the knees of the experimental animals were conducted by measuring (in millimeters) the lateral diameter of the right knee.

A digital radiological evaluation occurred before inoculation and at the end of the experiment, with anteroposterior (AP) and lateral incidences. The severity of arthritis was determined according to the quantification scale of radiological signs of osteoarthritis of the knee according to KELLGREN \& LAWRENCE ${ }^{19}$, which assigns scores from 0 to 5 in the presence of zero radiological findings, followed by minimal changes, moderate and severe for knee osteoarthritis.

After completion of the $\mathrm{Pb}$ exposure time (15 or 45 days of infection), the animals were anesthetized with ketamine and xylazine intraperitoneally. Blood samples were then collected, and the spleen, liver and lungs were extracted to recover viable fungi by plating and for histological processing. The product of the dissection of the right knee joint of the hind limb of each animal was fixed in $10 \%$ formalin solution, decalcified in 5\% trichloroacetic acid (TCA for approximately five days and processed for embedment in paraffin to obtain histological cuts, which, like other organs, were stained with silver using the Grocott method to visualize the $P$. brasiliensis ${ }^{16}$, and hematoxylin-eosin ${ }^{18}$ for general morphological analysis of tissues. The severity of arthritis was evaluated using the scale of arthritis, according to HANSCH et $a l .{ }^{17}$, assigning 0-3 points to the presence and intensity of mesothelium findings, such as hyperplasia of the synovial membrane, cell infiltrate in synovial tissue, pannus formation, and cartilage destruction.
ELISA (enzyme-linked immunosorbent assay) was performed as described by RAMOS et al. ${ }^{30}$. Briefly, 96 well plates were sensitized with the purified antigen gp43. After washing the plates, pooled sera were added $(100 \mu \mathrm{L})$ at $1: 1,1: 50,1: 450$ and $1: 1,350$, followed by reaction with the secondary antibody (anti-IgG peroxidase, Sigma-Aldrich ${ }^{\circledR}$ ). Fifty microliters per well (at a dilution of 1:1,000) was added, and the assays were developed and read the absorbance at $492 \mathrm{~nm}$.

The recovery of viable fungi was performed by plating in triplicates, macerated fragments of lung, spleen and liver from the rats. Macerated organs were homogenized in one $\mathrm{mL}$ of sterile PBS, after which $50 \mu \mathrm{L}$ were seeded on Petri dishes that contained BHI solid media supplemented with $P$. brasiliensis culture filtrate and horse serum, according to CASTAÑEDA et al. ${ }^{7}$. Colony forming units (cfu) were counted between seven and 15 days.

Numerical variables were analyzed with simple descriptive statistics and inferential statistics using Student's t-test, Wilcoxon and ANOVA for comparisons between groups. To verify the association between the time of exposure to the fungus and the degree of intensity of the arthritis, we used the Chi-square test. The significance level was $5 \%$ with a value of $\alpha$ set at $p<0.05$.

\section{RESULTS}

Swelling: In all experimental groups, the swelling measurements indicated increased joint volumes after the sixth day of inoculation to day 30 , with a peak in swelling production between the $10^{\text {th }}$ and $20^{\text {th }}$ day of exposure. In GCA and GCN, there was no statistically significant difference (Table 1).

Radiological evaluation: The Chi-square test showed a statistically significant association $(p=0.013)$ between the degree of arthritis and exposure to the fungus. In the GE group infected with $10^{5}$ yeast cells, all animals on day 45 displayed severe arthritis using the scale quantification of osteoarthritis of Kellgren \& Lawrence. The other groups had no statistically significant ( $p=0.241$ for both groups) observable indexes.

At the end of the experiment, it was observed that $100 \%$ of the animals in the GE group had abnormal findings ranging from mild to severe. At day 15 , clamping of the joint space, sclerosis of the marginal bone, a few irregularities of bone surfaces, lytic lesions and soft tissue swelling were observed. At day 45 of infection, additional changes were found, i.e., irregularities or no core lining, epiphyseal growth tubercle of the tibia epiphyses and flattening of the articular cartilage damage (Fig. 1).

Colony Forming Unit: The cfu results indicate recovery of viable yeasts in $14 \%$ of the experimental group animals sacrificed at 45 days. In the other groups, fungi were not recovered by plating. For the SG-10 yeast cells, three animals displayed PCM at other sites (lung, spleen and liver). The Chi-square test showed no statistically significant association between yeast dissemination and dose.

Anatomopathological analysis: The degree of arthritis was severe in all GE animals sacrificed at 45 days that received a dose of $10^{5}$ yeast cells, according to the index postulated by $\mathrm{HANSCH}$ et al. ${ }^{17}$. In the other groups $\left(10^{3}\right.$ and $10^{4}$ yeast cells), the degree of arthritis ranged from moderate to severe after 45 days of exposure. The Wilcoxon test 


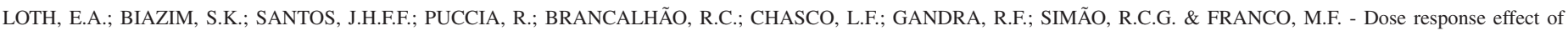
Paracoccidioides brasiliensis in an experimental model of arthritis. Rev. Inst. Med. Trop. Sao Paulo, 56(3): 259-64, 2014.

Table 1

The mean and standard deviations of the diameters for the GE, GCN and GCA joints before and after inoculation with P. brasiliensis at 15 and 45 days of exposure

\begin{tabular}{|c|c|c|c|c|c|c|c|c|}
\hline \multirow{2}{*}{ GROUP } & \multicolumn{4}{|c|}{15 DAYS } & \multicolumn{4}{|c|}{45 DAYS } \\
\hline & Start & End & $\%$ & $p$ value & Start & End & $\%$ & $p$ value \\
\hline GE $-10^{3}$ & $11.0 \pm 0.26$ & $15.30 \pm 1.77$ & 39.1 & $0.0002^{*}$ & $10.20 \pm 0.24$ & $12.40 \pm 1.30$ & 21.60 & $0.0001^{*}$ \\
\hline GE $-10^{4}$ & $10.40 \pm 0.31$ & $14.90 \pm 2.89$ & 42.3 & $0.0002^{*}$ & $10.18 \pm 0.51$ & $11.83 \pm 1.24$ & 16.25 & $0.0001^{*}$ \\
\hline GE $-10^{5}$ & $9.58 \pm 0.35$ & $12.45 \pm 0.63$ & 30 & $0.0001^{*}$ & $10.65 \pm 0.23$ & $12.03 \pm 1.02$ & 12.96 & $0.0001^{*}$ \\
\hline GCN-10 & $10.27 \pm 0.34$ & $10.30 \pm 0.47$ & 0.35 & 0.754 & $10.35 \pm 0.27$ & $10.42 \pm 0.54$ & 0.68 & 0.784 \\
\hline GCN-10 4 & $10.40 \pm 0.35$ & $10.42 \pm 0.42$ & 0.20 & 0.375 & $10.10 \pm 0.28$ & $10.40 \pm 0.41$ & 5.23 & 0.078 \\
\hline GCN-10 & $10.23 \pm 0.24$ & $10.33 \pm 0.48$ & 0.9 & 0.235 & $10.36 \pm 0.34$ & $10.63 \pm 0.47$ & 2.6 & 0.329 \\
\hline GCA & $10.74 \pm 0.42$ & $10.78 \pm 0.50$ & 0.37 & 0.255 & $10.71 \pm 0.31$ & $10.78 \pm 0.39$ & 0.65 & 0.902 \\
\hline
\end{tabular}

$\mathrm{GE}-10^{3}$ - Experimental group inoculated with $10^{3}$ viable yeast cells; GE - $10^{4}$ - Experimental group inoculated with $10^{4}$ viable yeast cells; GE - $10^{5}$ - Experimental group inoculated with $10^{5}$ viable yeast cells; GCN $-10^{3}$ - Experimental group inoculated with $10^{3}$ heat-inactivated yeast cells; GCN - $10^{4}$ - Experimental group inoculated with $10^{4}$ heat-inactivated yeast cells; GCN $-10^{5}$ - Experimental group inoculated with $10^{5}$ heat-inactivated yeast cells; GCA - Absolute control group.

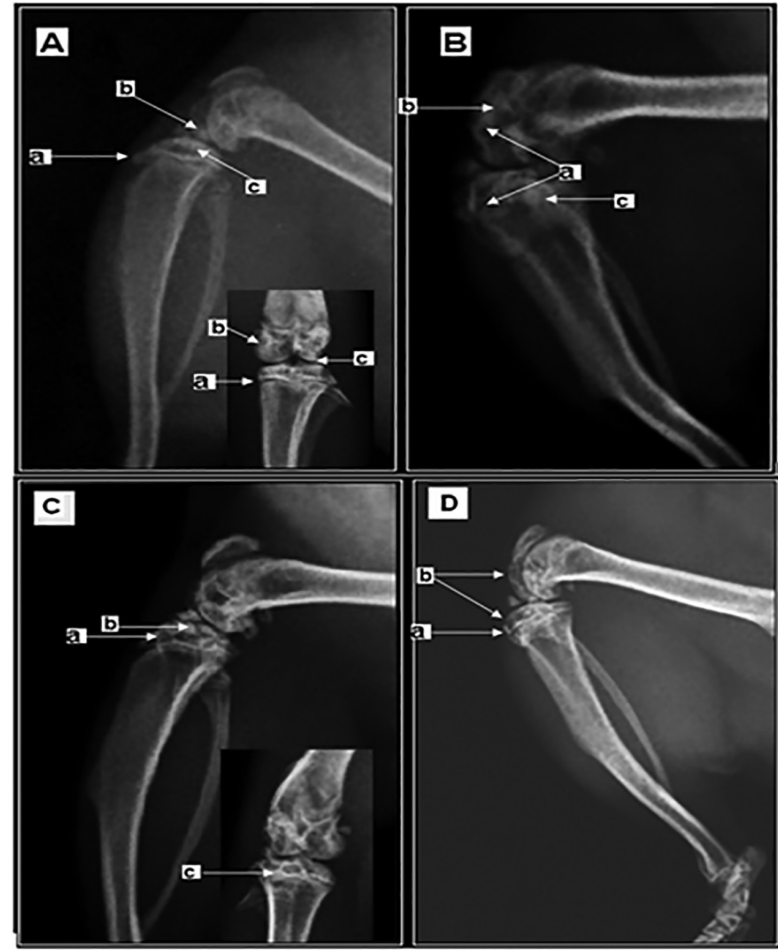

Fig. 1 - Radiological image of the right knee. A - A CGA animal on day 45 of the experiment presenting aspects compatible with normality. The arrow (a) indicates full epiphyseal line, the trabecular bone in the femur is regular (arrow (b)) and the regularity of the articular surface of the tibia and femur, indicated by the arrow (c). B - A GE animal ( $10^{5}$ yeast cells) on day 45 of the experiment displaying severe arthritis with joint destruction (arrow (a)), the absence of the patella-femoral joint space, shown by the arrow (b), and the absence of the epiphyseal line (arrow (c)). C - A GE animal on day 45 (inoculated with $10^{4}$ viable yeast cells) at the end of the study presents radiological findings consistent with mild arthritis. (a) Tibial subchondral cysts, (b) discontinuity of the articular surface of the tibia and (c) points to a deformity of the epiphyseal line adjacent to a subchondral cyst. D - A GE animal on day 15 (inoculated with $10^{3}$ viable yeast cells) presenting radiological findings consistent with mild arthritis. It is observed that the epiphyseal line is preserved (a) and that there are lytic lesions in the tibia and patella. indicated significant differences between the mean values obtained at 15 and 45 days in all groups ( $p=0.006, p=0.008$ and $p=0.011$ ). The Chi-square test showed no association between the intensity of arthritis and the yeast dose used.

The joint biopsies indicated the presence of granulomatous inflammation in the synovium tuberculoid type in $100 \%$ of the experimental group animals sacrificed at 15 and 45 days post-infection with viable yeast cells. The formation of necrosis and the destruction of articular cartilage were observed in the GE animals sacrificed at 45 days regardless of the dose used (Fig. 2).

Analysis of Antibodies by ELISA: The analysis of titration of antigp43 antibodies showed a higher production of specific antibodies in the groups corresponding to GE- $15 / 10^{3}$ and GE- $45 / 10^{3}$. In the other groups (both the experimental and negative controls), there were no statistically significant differences when comparing the groups (Fig. 3).

\section{DISCUSSION}

Questions about the clinical manifestations of fungal arthritis that are different from the clinical manifestations induced by bacterial arthritis, as described by FIGUEIREDO et al. ${ }^{14}$, justify the development of the present experimental model.

There are few publications in the literature on PCM articular involvement, and some are controversial in relation to their most frequently obtained findings ${ }^{13,32}$.

Experimental models have been used to elucidate mechanisms of common diseases in humans. Experimental models of PCM have allowed the acquisition of important information on various aspects of the disease and are able to provide monitoring of the infection from the beginning, which is not possible in human studies from biopsies and autopsies ${ }^{21}$.

In the present study, the results showed greater swelling formation between the seventh day of inoculation and the following thirty days. 


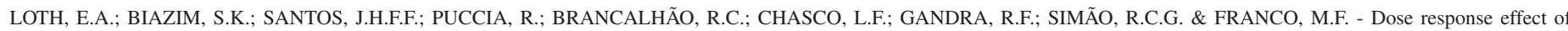
Paracoccidioides brasiliensis in an experimental model of arthritis. Rev. Inst. Med. Trop. Sao Paulo, 56(3): 259-64, 2014.

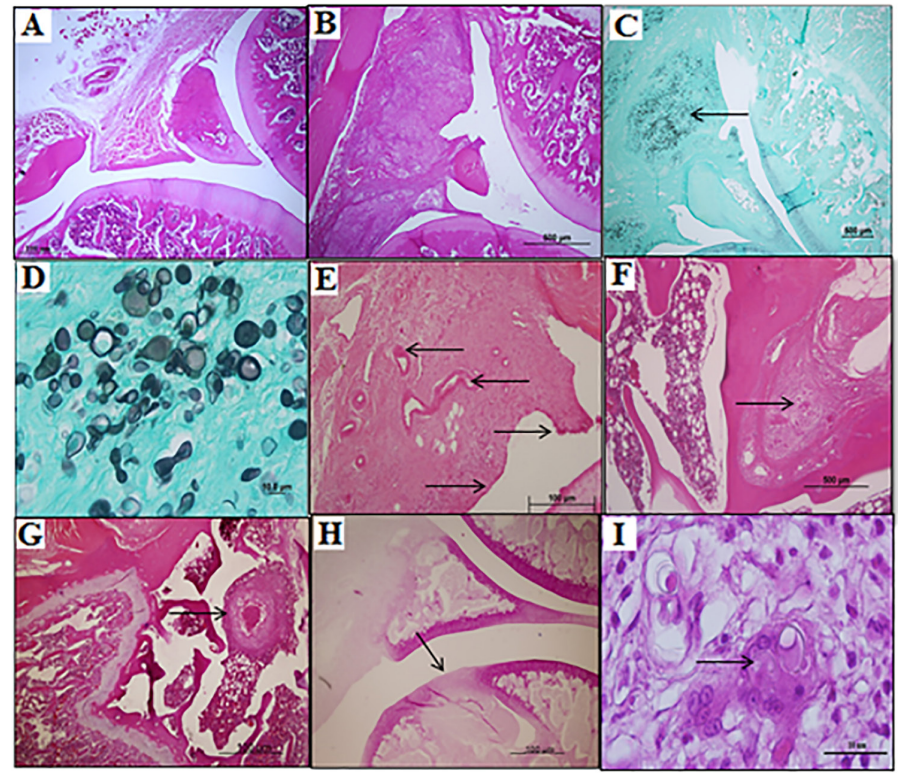

Fig. 2 - Photomicrographs of histological longitudinal sections from the knees of the experimental animals. A - Articulation of a normal animal, GCA (HE 4x). B - Synovial membrane with swelling and granuloma from an animal after 15 days of exposure to a dose of $10^{3}$ yeast cells (HE 4x). C - Synovial swelling with a large amount of P. brasiliensis cells, indicated by the arrow, from an animal exposed to a dose of $10^{4}$ yeast cells for 15 days (Grocott 4x). D - Detail of figure (C) with a large amount of P. brasiliensis cells with budding (Grocott 40x). E - Pannus formation with the emergence of vessels (left arrow) and the multilayered synovial mesothelium (the arrows to the right) at 45 days exposure (HE 10x). F - Granuloma with a giant cell bone inside (HE 10x). G - Granuloma bone above the epiphyseal line, focusing on the necrosis inside, in one animal after 45 days of exposure to $10^{5}$ viable yeast cells ( $\mathrm{HE} 4 \mathrm{x}$ ). $\mathbf{H}$ - The arrow indicates the area of cartilage destruction, with a deep necrotic area after 45 days of exposure to $10^{5}$ viable yeast cells (HE $4 \mathrm{x}$ ). I - Detail of figure (F) with a giant cell with $P$. brasiliensis cells inside (HE 100x).

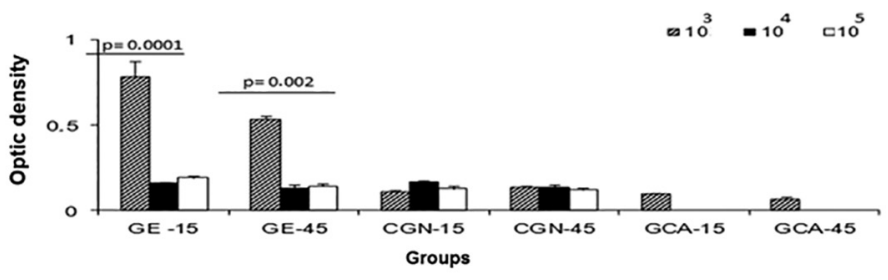

Fig. 3 - ELISA results for rat sera and gp43. The graph shows the mean optical density (1:50 dilution) obtained in the study groups after infection. $* p=0.0001$ and $p=0.002$ (ANOVA test) between the experimental groups at days 15 and 45 .

After this period, a reduction and stabilization of swelling was noted. The peak formation of swelling was between 10 and 20 days of the study regardless of the dose.

Our findings were similar to those reported by AMANAI et al. ${ }^{1}$, who investigated the morphology and micro-architecture of articular structures in an experimental model of osteoarthritis using mice intravenously inoculated with Candida albicans and observed that the knee swelling lasted for 26 days on average. In another study conducted using the same experimental model, NAKAMURA et al. ${ }^{27}$ reported peak swelling formation between 12 and 20 days, with reductions in the swelling after 31 days.
To assess the capacity of Candida albicans to induce arthritis, this yeast was directly injected into the joints of the mice paws. The authors observed peak erythema and swelling formation after seven days of the experiment with a slow decline for up to 35 days $^{37}$.

In our study, data not shown indicated that more concentrated infusions containing $10^{8} \mathrm{P}$. brasiliensis cells led to erythema and a swelling pattern similar to the data described in this text. However, no study on joint experimental PCM was found in the literature, which limits a more detailed discussion on the topic.

In the present study, it was observed that a dose of $10^{3}$ viable yeast cells resulted in the increased expression of anti-gp43 antibodies measured at days 15 and 45 of the experiment. These findings possibly occurred because, in this group, there was a higher number of cfu and an increased systemic dissemination of the fungus after 45 days of the experiment with an increased fungal burden and, consequently, the production of antibodies. However, at 15 days, we hypothesize that although there was a high specificity to the antigen used, there may be a reaction with immunoglobulin isotypes, such as IgM. BLOTTA \& CAMARGO $^{5}$ also found $\operatorname{IgM}$ in a sample obtained from patients presenting forms of chronic and acute PCM. BUENO et al. ${ }^{6}$ and BENARD et al. ${ }^{4}$ determined increased IgM expression in early PCM infections. BAIDA et al. ${ }^{2}$ and BENARD et al. ${ }^{4}$ also found increased levels of IgM during early PCM infections.

Independent of the amount of yeast used for the infection, the radiological changes found in the animals sacrificed after 15 days were similar, and the same results were observed in the animals sacrificed after 45 days of the experiment. However, these groups had more severe radiographic alterations.

The radiological findings of this study are similar to those described in a case of hip monoarthritis PCM in patient 29 with clamping joint ${ }^{31}$. Other radiological findings, described in 19 cases of osteoarticular PCM as osteolytic lesions and marginal sclerosis, as described by MONSIGNORE et al. $^{25}$, bone flattening ${ }^{15}$ irregularities of the trabecular bone ${ }^{23}$, joint swelling and the destruction of articular cartilage, which were indistinguishable from other infectious processes ${ }^{10}$, were also present among our findings.

MONSIGNORE et al. $^{25}$ studied the radiological findings of 19 cases of osteoarticular PCM and reported that, in all cases, osteolytic lesions were found. Other studies have also reported that lytic bone lesions are a characteristic of radiological involvement ${ }^{9,11}$ with or without marginal sclerosis $^{7,13}$.

Regarding the evaluation of anatomopathological quality, in the experimental groups sacrificed at 15 days, inflammatory signals (synovitis) were predominant and articular cartilage or necrotic areas were not observed. In the groups of animals sacrificed after 45 days, necrotic areas with deep lines near the epiphyseal, articular cartilage destruction and pannus formation were observed.

The commitment of the synovial membrane is described as the initial phase of PCM joint damage ${ }^{35}$, and the spread of the fungus often occurs secondary to a primary focus for hematogenous, lymphatic or contiguous $^{20,35}$. In this study, we induced an opposite pathway where the 
LOTH, E.A.; BIAZIM, S.K.; SANTOS, J.H.F.F.; PUCCIA, R.; BRANCALHÃO, R.C.; CHASCO, L.F.; GANDRA, R.F.; SIMÃO, R.C.G. \& FRANCO, M.F. - Dose response effect of Paracoccidioides brasiliensis in an experimental model of arthritis. Rev. Inst. Med. Trop. Sao Paulo, 56(3): 259-64, 2014.

fungus was inoculated directly into the joint and, with disease progression the invasion to adjacent bones could be observed, indicating a severe degree of arthritis and systemic dissemination, as part of the disease during the 45 days of this study.

The data obtained using the scale of the intensity of arthritis ${ }^{17}$ showed statistically significant differences only when comparing the scores of the experimental groups sacrificed at day 15 with the scores of the groups sacrificed at day 45 of the study. Thus, the dose of infused yeast cells and the time of exposure to the fungus were essential for inducing severe arthritis in the knees of the animals, and we were able to determine the increased intensity of the arthritis. After the $15^{\text {th }}$ day of the experiment, the anatomopathological findings were restricted to the articulation. After 45 days, the extent of the damage to the subchondral bone was observed, sometimes almost reaching the line of epiphyseal growth and causing systemic dissemination.

\section{CONCLUSION}

It was concluded that the doses of yeast used caused arthritis in the experimental animals. After 15 days, there were more intense inflammatory signs and, after 45 days of exposure, the predominant phenomenon of joint degeneration was present. In addition, a dose of $10^{5}$ viable yeast cells was the standard dosage for the development of our experimental model.

\section{RESUMO}

\section{Efeito da dose resposta de Paracoccidioides brasiliensis no modelo experimental de artrite}

A paracoccidioidomicose ( $\mathrm{PCM})$ é causada pelo fungo dimórfico Paracoccidioides brasiliensis $(\mathrm{Pb})$ e corresponde à micose sistêmica de maior prevalência na América Latina. O objetivo do presente trabalho foi avaliar a dose resposta de leveduras do fungo para padronização do modelo experimental de artrite séptica. Os experimentos foram realizados com grupos de 14 ratos que receberam doses de $10^{3}, 10^{4}$ ou $10^{5}$ células de $P$. brasiliensis (Pb18). Os fungos foram injetados em $50 \mu \mathrm{L}$ de solução salina em tampão fosfatado (PBS) diretamente na articulação do joelho dos animais. Os seguintes parâmetros foram analisados neste trabalho: a formação de edema nos joelhos infundidos com as células das leveduras e alterações radiológicas, anatopalógicas além de titulação de anticorpos por Elisa. Após 15 dias de infecção, os sinais de inflamação foram evidentes. Aos 45 dias, algumas características de dano e necrose foram observadas na cartilagem articular. A disseminação sistêmica do fungo foi observada em $11 \%$ dos animais inoculados, concluiu-se que o modelo experimental é capaz de mimetizar a PCM articular em humanos e que a dose de $10^{5}$ leveduras representa a dose padrão para o desenvolvimento do modelo.

\section{ACKNOWLEDGMENTS}

We thank the Department of Pathology and Department of Microbiology of the School of Medicine of UNIFESP (São Paulo, SP). This work was supported by "Fundação Araucária-Fundo Paraná/SETI" (agreement 1276/2012). S. K. Biazim is a fellow of the "Fundação Araucária" (PIBIC-Ações afirmativas).

\section{REFERENCES}

1. Amanai T, Nakamura Y, Aoki S, Mataga I. Micro-CT analysis of experimental Candida osteoarthritis in rats. Mycopathologia. 2008;166:133-41.

2. Baida H, Biselli PJ, Juvenale M, Del Negro GM, Mendes-Giannini MJ, Duarte AJ, et al. Differential antibody isotype expression to the major Paracoccidioides brasiliensis antigen in juvenile and adult form paracoccidioidomycosis. Microbes Infect. $1999 ; 1: 273-8$

3. Baransky MC, Silva AF, Rodrigues D. Lesões ósseas e osteoarticulares. In: Del Negro G, Lacaz CS, Fiorillo AM, editores. Paracoccidioidomicose: blastomicose sul-americana. São Paulo: Sarvier-Edusp; 1982. p. 211-9.

4. Benard G, Mendes-Giannini MJ, Juvenale M, Miranda ET, Duarte AJ. Immunosuppression in paracoccidioidomycosis: T cell hyporesponsiveness to two Paracoccidioides brasiliensis glycoproteins that elicit strong humoral immune response. J Infect Dis. 1997; 175:1263-7.

5. Blotta MH, Camargo ZP. Immunological response to cell-free antigens of Paracoccidioides brasiliensis: relationship with clinical forms of paracoccidioidomycosis. J Clin Microbiol. 1993;31:671-6.

6. Bueno JP, Mendes-Giannini MJ, Del Negro GM, Assis CM, Takiguti CK, ShikanaiYasuda MA. IgG, IgM and IgA antibody response for the diagnosis and follow-up of paracoccidioidomycosis: comparison of counterimmunoelectrophoresis and complement fixation. J Med Vet Mycol. 1997;35:213-7.

7. Castañeda E, Brummer E, Pappagianis D, Stevens DA. Impairment of cellular but not humoral immune responses in chronic pulmonary and disseminated paracoccidioidomycosis in mice. Infect Immun.1988;56:1771-7.

8. Castañeda OJ, Alarcón GS, García MT, Lumbreras H. Paracoccidioides brasiliensis arthritis. Report of a case and review of the literature. J Rheumatol. 1985;12:356-8.

9. Correa-de-Castro B, Pompilio MA, Odashiro DN, Odashiro M, Arão-Filho A, Paniago AM Unifocal bone paracoccidioidomycosis, Brazil. Am J Trop Med Hyg. 2012;86:470-3.

10. Costa MA, Carvalho TN, Araújo CR Jr, Borba AO, Veloso GA, Teixeira KS. Extrapulmonary manifestations of paracoccidioidomycosis. Radiol Bras. 2005;38:45-52.

11. Da Rocha FF, Campos MG. Monoartrite como manifestação de paracoccidioidomicose Rev Panam Infectol. 2007;9:31-3.

12. David A, Telöken MA, Dalmina V, de Oliveira GK, de Oliveira RK. Paracoccidioidomicose óssea: relato de caso. Rev Bras Ortop. 1997;32:254-6

13. Doria AS, Taylor GA. Bony involvement in paracoccidioidomycosis. Pediatr Radiol. 1997;27:67-9.

14. Figueiredo GC, Figueiredo EC, Tavares-Neto J. Artrite fúngica: análise secundária de dados. Rev Bras Ortop. 2002;37:259-69.

15. Franco L, Najvar L, Gómez BL, Restrepo S, Graybill JR, Restrepo A. Experimental pulmonary fibrosis induced by Paracoccidioides brasiliensis conidia: measurement of the host local responses. Am J Trop Med Hyg. 1998;58:424-30.

16. Grocott RG. A stain for fungi in tissue sections and smears using Gomori's methenaminesilver nitrate technic. Am J Clin Pathol. 1955;25:975-9.

17. Hansch A, Frey O, Gajda M, Susanna G, Boettcher J, Bräuer R, et al. Photodynamic treatment as a novel approach in the therapy of arthritic joints. Lasers Surg Med. 2008;40:265-72.

18. Junqueira LC, Bignolas G, Brentani RR. Picrosirius staining plus polarization microscopy, a specific method for collagen detection in tissue sections. Histochem J. 1979;11:44755 . 
LOTH, E.A.; BIAZIM, S.K.; SANTOS, J.H.F.F.; PUCCIA, R.; BRANCALHÃO, R.C.; CHASCO, L.F.; GANDRA, R.F.; SIMÃO, R.C.G. \& FRANCO, M.F. - Dose response effect of Paracoccidioides brasiliensis in an experimental model of arthritis. Rev. Inst. Med. Trop. Sao Paulo, 56(3): 259-64, 2014.

19. Kellgren JH, Lawrence JS. Radiological assessment of osteo-arthrosis. Ann Rheum Dis. $1957 ; 16: 494-502$

20. Kemper CA, Deresinski SC. Fungal disease of bone and joint. In: Kibbler CC, Mackenzie DW, Odds FC, editors. Principles and practice of clinical mycology. Chichester: John Wiley; 1996. p. 49-68.

21. Kerr IB, de Oliveira PC, Lenzi HL. Connective matrix organization in chronic granulomas of experimental paracoccidioidomycosis. Mycopathologia. 1988;103:11-20.

22. Lacaz CS, Porto E, Martins JEC, Heins-Vaccari EM, Mello NT. Paracoccidioidomicose. In: Micologia médica. São Paulo: Sarvier; 2002. p. 639-729.

23. Lambertucci JR, Botelho JS, Melo FH. Osteomielite pelo Paracoccidioides brasiliensis. Rev Soc Bras Med Trop. 2002;35:271-2.

24. Londero AT, Melo IS. Paracoccidioidomicose (Blastomicose Sul Americana, Doença de Lutz-Splendore-Almeida). J Bras Med.1988;55:96-111.

25. Monsignore LM, Martinez R, Simão MN, Teixeira SR, Elias J Jr, Nogueira-Barbosa MH. Radiologic findings of osteoarticular infection in paracoccidioidomycosis. Skeletal Radiol. 2012;41:203-8.

26. Mota CC. Contribuição ao estudo da epidemiologia da blastomicose sul americana no Paraná. An Fac Med Univ Fed Paraná. 1996;9:53-92.

27. Nakamura Y, Noda S, Masuhara T, Ito-Kuwa S, Nakamura K, Aoki S. Radiographic features of experimental Candida arthritis in rats. Mycopathologia. 1993;121:65-75.

28. Negroni R. Paracoccidioidomycosis (South American Blastomycosis, Lutz's mycosis). Int J Dermatol. 1993;32:847-59.

29. Pereira RM, Bucaretchi F, Barison EM, Tresoldi AT. Paracoccidioidomycosis in children: clinical presentation, follow-up and outcome. Rev Inst Med Trop Sao Paulo. 2004;46:127-31.
30. Ramos SP, Sano A, Ono MA, Camargo ZP, Estevão D, Miyaji M, et al. Antigenuria and antigenaemia in experimental murine paracoccidioidomycosis. Med Mycol. 2005;43:631-6.

31. Resnik CS, Resnick D. Radiology of disorders of the sacroiliac joints. JAMA 1985;253:2863-6.

32. Rosario-Filho NA, Telles-Filho FQ, Costa O, Marinoni LP. Paracoccidioidomycosis in children with different skeletal involvement. Rev Inst Med Trop Sao Paulo. $1985 ; 27: 337-40$

33. Severo LC, Agostini AA, Londero AT. Acometimento ósseo na paracoccidioidomicose crônica disseminada. Rev Soc Bras Med Trop. 1996;29:241-4.

34. Shikanai-Yasuda MA, Telles-Filho F de Q, Mendes RP, Colombo AL, Moretti ML. Consenso em paracoccidioidomicose. Rev Soc Bras Med Trop. 2006;39:297-310.

35. Silvestre MT, Ferreira MS, Borges AS, Rocha A, de Souza GM, Nishioka SA. Monoartrite de joelho como manifestação isolada de paracoccidioidomicose. Rev Soc Bras Med Trop. 1997;30:393-5.

36. Wanke B, Londero AT. Epidemiology and paracoccidioidomycosis infection. In: Franco MF, Del Negro G, Lacaz CS, Restrepo-Moreno A, editors. Paracoccidioidomycosis. Boca Raton: CRC Press; 1994. p. 109-20.

37. Yordanov M, Danova S, Ivanovska N. Inflammation induced by inoculation of the joint with Candida albicans. Inflammation. 2004;28:127-32.

Received: 2 August 2013

Accepted: 23 October 2013 